\title{
Penguatan Nilai Karakter Masyarakat untuk Mendukung Pengembangan Pariwisata
}

\author{
Buchory MS ${ }^{1}$, Okti Purwaningsih ${ }^{2}$, Triwahana ${ }^{3}$ \\ 1,2,3) Universitas PGRI Yogyakarta \\ 1) buchoryupy@yahoo.com
}

\begin{abstract}
Indonesia sebagian besar merupakan wilayah perairan dengan panjang garis pantai $81.000 \mathrm{~km}$. Pantai Parangtritis sebagai salah satu aset objek wisata Indonesia terletak di Desa Parangtritis, Kecamatan Kretek, Kabupaten Bantul, DIY. Sebagian besar objek wisata yang ada di Parangtritis terletak di Dukuh Mancingan yang memiliki wisata pantai, gumuk pasir, dan ziarah. Sebagai daerah pariwisata banyak permasalahan yang dihadapi antara lain permasalahan ekonomi, sosial, dan lingkungan hidup. Termasuk permasalahan sosial adalah maraknya prostitusi yang dikawatirkan akan berdampak pada disintegritas karakter masyarakat. Permasalahan lingkungan seperti kerusakan lingkungan yang menjadi ancaman bagi pengembangan sektor pariwisata di Mancingan. Berdasarkan permasalahan tersebut tim pengabdian dan mitra menyepakati untuk menyelesaikan permasalahan disintegritas nilai-nilai karakter dan lingkungan hidup. Metode yang digunakan dalam pengabdian ini adalah penyuluhan dan pelatihan. Kegiatan direncanakan dilaksanakan dalam tiga kali pertemuan yaitu (1) penyuluhan tentang nilainilai kearifan lokal, (2) penyuluhan tentang budaya dan sejarah Parangtritis dan Parangkusumo, (3) penyuluhan tentang lingkungan hidup dan pelatihan tentang pengelolaan sampah. Penguatan nilai karakter masyarakat untuk mendukung pengembangan pariwisata dilakukan melalui pembentukan keluarga Pancasila, mem-Pancasila-kan pendidikan nasional, dan pembentukan masyarakat Pancasila.
\end{abstract}

\section{PENDAHULUAN}

Indonesia merupakan negara kepulauan, dua per tiga wilayah Indonesia berupa lautan dengan panjang garis pantai $81.000 \mathrm{~km}$. Wilayah pesisir pantai memiliki potensi sumberdaya alam untuk dikembangkan. Potensi sumberdaya alam wilayah pesisir pantai cukup beragam antara lain dari sektor perikanan, peternakan, pertanian, dan pariwisata. Sektor-sektor tersebut jika dikembangkan secara tepat berpeluang untuk meningkatkan pertumbuhan ekonomi sehingga berdampak pada peningkatan kesejahteraan masyarakat, terutama pengembangan sektor pariwisata dapat menggiatkan perekonomian masyarakat. Menurut Syarief (2010) memberdayakan masyarakat pesisir tidak seperti memberdayakan kelompok-kelompok masyarakat lainnya karena di dalam habitat pesisir terdapat banyak kelompok kehidupan masyarakat antara lain masyarakat nelayan tangkap, nelayan pengumpul/bakul, nelayan buruh, nelayan tambak, petani, dan pelaku usaha pariwisata. Masing-masing kelompok masyarakat tersebut memerlukan pendekatan yang berbeda, sehingga program pemberdayaan masyarakat pesisir harus didesain dengan tidak menyamaratakan antara satu kelompok dengan kelompok yang lain, antara wilayah pesisir satu dengan yang lain.

Mancingan adalah sebuah pedukuhan yang terletak di Desa Parangtritis, Kecamatan Kretek, Kabupaten Bantul Daerah Istimewa Yogyakarta. Wilayah Mancingan XI berbatasan sebelah timur dengan Purwosari Gunung Kidul, sebelah utara dengan Grogol X, sebelah barat dengan Grogol X. Luas wilayah Mancingan adalah 140.563,5 ha dengan jumlah KK sebanyak 414 kepala keluarga yang tersebar dalam delapan RT. Jumalah penduduk Mancingan
1282 jiwa, terdiri atas jenis kelamin laki-laki 620 orang dan perempuan 662 orang. Penduduk berusia produktif berjumlah 680 orang. Mancingan memiliki kekayaan sumberdaya alam yang menjadi daya tarik wisatawan yaitu Pantai Parangtritis dan Pantai Parangkusumo.

Penduduk Dukuh Mancingan mayoritas bermata pencaharian sebagai wirausaha. Sebagian besar penduduk menggantungkan hidupnya dari hasil berwirausaha terutama pada sektor pendukung pariwisata. Sejak adanya pengembangan wisata parangtritis maka memberikan keuntungan tersendiri bagi warga masyarakat setempat. Obyek wisata yang cukup menarik dan tingkat kunjungan wisata yang relatif ramai mampu memberikan penghasilan yang cukup tinggi bagi masyarakat sehingga tingkat perekonomian mereka juga semakin meningkat (Purwaningsih, dkk., 2015). Penduduk Mancingan mempunyai beberapa organisasi pemberdayaan diantaranya adalah organisasi kelompok usaha di sektor pariwisata yang dibagi kedalam enam zona. Keenam zona tersebut adalah Zona I (Porangan Indah), Zona II (Ngudi Rejeki), Zona III (Guyub Rukun), Zona IV (Anugerah Tirta), Zona V (Berkah Wisata), dan Zona VI (Upaya Boga). Disamping keenam zona tersebut masih ada organisasi Gapoktan dan organisasi kepemudaan.

Sebagai daerah wisata yang telah tersohor sampai ke manca negara, Dukuh Mancingan juga rentan terkena dampak negatif pariwisata. Penelitian yang dilaksanakan oleh Purwaningsih, dkk. (2015), adanya fenomena 'wisata ziarah' setiap malam selasa kliwon dan jumat kliwon yang menyisakan sisa kelam kehidupan malam di pantai selatan dengan adanya praktik prostitusi. Jika hal tersebut dibiarkan 
secara terus menerus dikuatirkan akan berdampak kepada pertumbuhan generasi muda. Oleh karena itu perlu adanya pendampingan dari perguruan tinggi, pemerintah, dan swasta agar generasi muda di Mancingan tetap memiliki nilai-nilai karakter dan menjunjung tinggi budaya serta kearifan lokal dari para leluhur.

Permasalahan yang dihadapi masyarakat Dukuh Mancingan XI, Desa Parangtritis, Kecamatan Kretek, Kabupaten Bantul DIY sangat komplek. Sebagai tempat wisata yang sudah dikenal masyarakat baik nasional maupun internasional, disamping mempunyai potensi sumberdaya alam yang mempunyai nilai jual, berbagai permasalahan muncul sebagai dampak dari kegiatan pariwisata antara lain masalah sosial (prostitusi) dan masalah sampah. Hasil penelitian Purwaningsih, dkk. (2015) membrikan gambaran kondisi objektif dan permasalahan-permasalahan yang berhasil diidentifikasi adalah sebagai berikut:

- Telah terbentuk asosiasi untuk mengelola kawasan wisata pantai Parangtritis tetapi asosiasi (zona) tersebut belum berfungsi dan berjalan dengan baik. Salah satu penyebabnya karena tidak mempunyai payung hukum dan belum mempunyai program kerja.

- Masalah penghijauan. Penghijauan di sekitar pantai Parangtritis, termasuk gumuk pasir sangat kurang sehingga pada siang hari sangat panas. Hal ini tentu saja mengurangi kenyamanan bagi wisatawan.

- Belum ada pengelolaan sampah secara baik, sampah banyak berserakan di berbagai tempat fasilitas umum pendukung pariwisata.

- Sarana prasarana tidak dapat dimanfaatkan secara oiptimal, sebagai contoh los pasar. Hal ini disebabkan karena program pemerintah tidak didasarkan pada kebutuhan masyarakat dan adanya tumpah tindih kepentingan. Pengelolaan wisata di Parangtritis dilakukan oleh empat instansi yaitu Dinas Pekerjaan Umum, Dinas Pariwisata, Dinas Perhubungan, dan Satpol PP. Program bersifat top down dan tidak meminta masukan dari masyarakat.

- Sebagian besar masyarakat menggantungkan hidupnya dari pariwisata yang ada di Pantai Parangtritis. Usaha yang dilakukan masyarakat Dukuh Mancingan XI antara lain adalah penginapan, parkir, warung makan, toilet, jasa andong, dan ATV. Usaha yang dilakukan oleh masyarakat tersebut belum terorganisir dengan baik.

- Sektor pertanian belum dapat menjadi sumber penghasilan pokok masyarakat, belum ada diversifikasi tanaman yang dibudidayakan. Lahan yang ada belum dimanfaatkan secara optimal untuk budidaya tanaman. Disamping itu belum dilakukan pengolahan hasil pertanian yang dapat menjadi ciri khas untuk mendukung pariwisata di Parangtritis.
- Masyarakat Dukuh Mancingan tidak dilibatkan dalam pengembangan wilayah/pembangunan yang dilakukan oleh pemerintah maupun swasta.

- Masalah sosial fenomena 'ziarah malam Selasa Kliwon dan Jumat Kliwon' yang meningkatkan kegiatan prostitusi dan menjamurnya usaha karaoke dengan girl karaoke.

Permasalahan diatas merupakan permasalahan yang dihadapi dalam pengelolaan wilayah pesisir pantai Dukuh Mancingan. Berdasarkan hasil diskusi dengan Kepala Dukuh Mancingan disepakati permasalahan yang dihadapi yang menjadi prioritas utama dalam kegiatan pengabdian kepada masyarakat, yaitu:

- Meningkatkan nilai-nilai karakter dengan mengangkat nilai-nilai kearifan lokal kepada para pemuda Mancingan sehingga mereka bisa tumbuh menjadi pemuda yang berkarakter Indonesia.

- Memperkenalkan budaya Indonesia, khususnya tentang budaya Jawa kepada para generasi muda sehingga menumbuhkan rasa nasionalisme.

- Meningkatkan kecintaan generasi muda terhadap lingkungan hidup untuk menjaga kelestarian lingkungan.

\section{MetOdE}

Langkah-langkah yang dilaksanakan untuk mengatasi permasalahan yang dihadapi oleh mitra dapat dijelaskan sebagai berikut:

- Mengidentifikasi permasalahan. Kegiatan ini dilakukan sebelum penyusunan proposal. Pengusul dan mitra melakukan identifikasi permasalahan dan solusi yang akan dipilih untuk mengatasi permasalahan tersebut.

- Melaksanakan penyuluhan dan pelatihan. Penyuluhan merupakan metode yang digunakan untuk menyelesaikan permasalahan yang dihadapi oleh mitra. Penyuluhan dilaksanakan selama tiga kali yaitu:

- Penyuluhan tentang nilai-nilai kearifan lokal. Kegiatan ini bertujuan untuk meningkatkan karakter masyarakat Mancingan, khususnya generasi muda.

- Penyuluhan tentang budaya dan sejarah Parangtritis \& Parangkusumo sehingga meningkatkan rasa nasionalisme.

- Penyuluhan tentang lingkungan hidup dan pelatihan pemanfaatan limbah rumah tangga/sampah sehingga meningkatkan peran aktif masyarakat dalam menjaga kelestarian lingkungan.

- Melakukan pendampingan kepada masyarakat Dukuh Mancingan, membantu memberikan solusi terhadap permasalahan yang ada di masyarakat sesuai kompetensi yang dimiliki oleh tim pengabdian kepada masyarakat.Melalui kegiatan pendampingan 
diharapkan mitra dapat mengimplementasikan pengetahuan dan ketrampilan yang diperoleh sehingga keberlanjutan program dapat terwujud. Pendampingan dilakukan secara periodik sesuai dengan perkembangan mitra. Pada kegiatan pendampingan ini meliputi hal-hal yang bersifat teknis dan manajemen. Metode yang digunakan dalam kegiatan pendampingan adalah dengan diskusi dan konsultasi.

Peran mitra dalam pelaksanaan program meliputi penyediaan SDM yang akan mengikuti pelatihan dan pendampingan, tempat dan bahan untuk kegiatan pelaksanaan program. Mitra juga bersedia untuk melaksanakan perubahan atau inovasi. Motivasi dan komitmen yang tinggi untuk maju menjadi modal bagi pelaksanaan dan keberlanjutan program.

Evaluasi pelaksanaan kegiatan pengabdian kepada masyarakat secara internal dilakukan oleh Lemabga Penelitian dan Pengabdian kepada Masyarakat (LPPM) UPY, disamping itu tim pengabdian melakukan evaluasi pelaksanaan program dengan melihat ketercapaian indikator yang telah ditetapkan. Evaluasi keberlanjutan program dilakukan untuk memantau apakah program masih berjalan setelah kegiatan pengabdian selesai dilaksanakan. Pemantauan dilakukan dengan tetap melakukan pendampingan kepada mitra meskipun kegiatan pengabdian telah selesai. Tim pengabdian masih tetap memberikan layanan konsultasi dan diskusi dengan mitra. Melalui cara tersebut evaluasi keberlanjutan program dapat dilaksanakan dan dipantau.

\section{Penguatan Nilai Karakter Masyarakat UntUK MENDUKUNG PENGEMBANGAN PARIWISATA}

Istilah kearifan lokal dapat dimaknai sebagai kebijakan setempat (local wisdom), pengetahuan setempat (local knowledge) atau kecerdasan setempat (local genious). Kearifan lokal juga dapat diartikan sebuah pemikiran tentang hidup. Pemikiran tersebut dilandasi nalar jernih, budi yang baik, dan memuat hal-hal positif. Kearifan lokal dapat diterjemahkan sebagai karya akal budi, perasaan mendalam, tabiat, bentuk perangai, dan anjuran untuk kemuliaan manusia. Penguasaan atas kearifan lokal akan mengusung jiwa mereka semakin berbudi luhur. Menurut Rahyono (2009:7) kearifan lokal merupakan kecerdasan manusia yang dimiliki oleh kelompok etnis tertentu yang diperoleh melalui pengalaman masyarakat. Maksudnya, kearifan lokal adalah hasil dari masyarakat tertentu melalui pengalaman mereka dan belum tentu dialami oleh masyarakat yang lain. Nilai-nilai tersebut akan melekat sangat kuat pada masyarakat tertentu dan nilai itu sudah melalui perjalanan waktu yang panjang, sepanjang keberadaan masyarakat tersebut. Kearifan lokal diyakini dapat meningkatkan dan mempertahankan karakter suatu masyarakat sehingga perlu dijaga kelestariannya di era globalisasi yang ditandai dengan perkembangan teknologi dan informasi.
Kearifan lokal, menurut John Haba sebagaimana dikutip oleh Irwan Abdullah (2008 : 7), "mengacu pada berbagai kekayaan budaya yang tumbuh dan berkembang dalam sebuah masyarakat yang dikenal, dipercayai dan diakui sebagai elemen-elemen penting yang mampu mempertebal kohesi sosial di antara warga masyrakat". Setidaknya ada enam signifikansi dan fungsi kearifan lokal jika dimanfaatkan dalam resolusi konflik, yaitu (1) sebagai penanda identitas sebuah komunitas; (2) elemen perekat (aspek kohesif) lintas warga, lintas agama dan lintas kepercayaan; (3) kearifan lokal tidak bersifat memaksa tetapi lebih merupakan kesadaran dari dalam; (4) kearifan lokal memberi warna kebersamaan sebuah komunitas; (5) kemampuan local wisdom dalam mengubah pola fikir dan hubungan timbal balik individu dan kelompok dan meletakkannya di atas common ground; (6) kearifan lokal dapat mendorong proses apresiasi, partisipasi sekaligus meminimalisir anasir yang merusak solidaritas dan integrasi komunitas. Terbitnya Undang-Undang Republik Indonesia Nomor 10 Tahun 2009 tentang Kepariwisataan, menjadi acuan bagi semua pihak dalam mengelola kepariwisataan di Indonesia. Pada dasarnya keseluruhan penyelenggaraan kepariwisataan mulai saat itu, mendasarkan pada kaidah yang terdapat pada undang-undang tersebut dan berbagai peraturan pelaksanaan sebagai turunannya. Kaidah yang diatur dalam Undang-Undang Kepariwisataan tersebut adalah bahwa kegiatan pembangunan kepariwisataan di Indonesia harus dilaksanakan berdasarkan pada asas manfaat, kekeluargaan, adil dan merata, keseimbangan, kemandirian, kelestarian, partisipatif, berkelanjutan, demokratis, kesetaraan, dan kesatuan. Menurut Sunarya (2013 : 99), kaidah tersebut diwujudkan dalam pelaksanaan rencana pembangunan kepariwisataan dengan memperhatikan keanekaragaman, keunikan, dan kekhasan budaya dan alam, serta kebutuhan manusia untuk berwisata. Sesuai dengan kaidah penyelenggaraan kepariwisataan yang ditegaskan di atas, dirumuskan tujuan kepariwisataan di Indonesia, adalah (a) meningkatkan pertumbuhan ekonomi,(b) meningkatkan kesejahteraan rakyat, (c) menghapus kemiskinan, (d) mengatasi pengangguran, (e) melestarikan alam, lingkungan dan sumber daya, (f) memajukan kebudayaan, (g) mengangkat citra bangsa, (h) memupuk rasa cita tanah air, (i) memperkukuh jati diri dan kesatuan bangsa, dan (j) mempererat persahabatan antar bangsa.

Dalam Undang-Undang Kepariwisataan juga ditegaskan bahwa untuk mewujudkan sepuluh tujuan penyelenggaraan kepariwisataan tersebut, maka kegiatan kepariwisataan di Indonesia dilaksanakan atas dasar prinsip-prinsip berikut : (1) menjunjung tinggi norma agama dan nilai budaya sebagai pengejawantahan dari konsep hidup dalam keseimbangan antara manusia dengan Tuhan Yang Maha Esa, hubungan antara manusia dengan sesama manusia dan hubungan antara manusia dengan lingkungan; (2) menjunjung tinggi hak asasi manusia, keragaman budaya dan kearifan lokal; (3) memberi manfaat untuk 
kesejahteraan rakyat, keadilan, kesetaraan, dan proporsionalitas; (4) memelihara kelestarian alam dan lingkungan hidup; (5) memberdayakan masyarakat setempat; (6) menjamin keterpaduan antar sektor, antar daerah, antar pusat dan daerah yang meerupakan satu kesatuan yang sistemik dalam kerangka otonomi daerah, serta keterpaduan antar pemangku kepentingan; (7) mematuhi kode etik kepariwisataan dunia dan kesepakatan internasional dalam bidang pariwisata, dan (8) memperkukuh Negara Kesatuan Republik Indonesia.

Sejalan dengan prinsip dan tujuan kepariwisataan tersebut, Hunter seperti dikutip oleh Kutanegara (2014 : 21) menyatakan bahwa hubungan antara penduduk dengan lingkungan harus mempertimbangkan tiga variabel kompleks, yaitu (1) vaiabel kependudukan yang meliputi jumlah dan pertumbuhan, distribusi, dan komposisi penduduk; (2) variabel lingkungan yang terdiri atas tanah, air dan sungai, serta udara; (3) faktor antara yang meliputi teknologi, konsteks institusi dan kebijakan, serta faktor kultural.

Dalam sistem pendidikan nasional Indonesia, masih terbatas dukungan lembaga pendidikan formal terhadap pembangunan sektor pariwisata. Lembaga pendidikan formal mulai dari tingkat Sekolah Dasar sampai dengan perguruan tinggi' belum memasukkan materi sapta pesona pariwisata dan terkait dengan pengembangan kepariwisataan ke dalam kurikulumnya. Dalam mensukseskan pembangunan pariwisata di Indonesia, maka yang perlu dilakukan adalah menumbukkembangkan sadar wisata karena merupakan akar dari sapta pesona. Sadar wisata merupakan sebuah konsep yang menggambarkan partisipasi dan dukungan masyarakat dalam mendorong terwujudnya iklim yang kondusif pengembangan kepariwisataan di suatu wilayah.

Menurut Friedmann (1992), untuk memberdayakan dan meningkatkan partisipasi masyarakat lokal terdapat persyaratan yang harus dipenuhi, yaitu ruang hidup yang memadai, pengelompokan sosial, keikutsertaan dalam jaringan sosial, alokasi waktu yang cukup, penguasaan informasi, peralatan produksi, keterampilan, dan akses terhadap sumber finansial. Ketersedian dan akses yang memadai terhadap prasyarat tersebut dapat digunakan sebagai indikator keberdayaan masyarakat. Sejalan dengan hal ini, Kutanegara (2014:23) mengemukakan bahwa dalam proses pemberdayaan terdapat empat dimensi kebudayaan yang perlu diperhatikan. Ke empat hal tersebut adalah (a) pelibatan konsepsi lokal tentang status dan peran sosial yang terdapat dalam masyarakat; (b) pola pengaturan hak yang berlaku dalam masyarakat lokal; (c) sistem akses dan kontrol yang berlaku dalam masyarakat lokal yang berbeda dengan sistem yang dibentuk oleh negara; (d) pengaturan kekuasaan dan pola pengambilan keputusan.

Adapun penguatan nilai karakter masyarakat untuk mendukung pengembangan pariwisata dilakukan dengan cara :

\section{A. Pembentukan Keluarga Pancasila}

Upaya membudayakan nilai-nilai Pancasila dan wawasan kebangsaan sebagai perekat keberagaman bangsa Indonesia, perlu dimulai sejak terjadi interaksi dalam skop terkecil kehidupan anak, yaitu keluarga. Secara sosiologis keluarga adalah institusi sosial yang terkecil masyarakat. Oleh karena itu perlu dibangun keluarga Pancasila. Keluarga Pancasila mengandung makna bahwa di dalam keluarga itulah ditanamkan dan disemaikan benih-benih implementasi nilai-nilai Pancasila dan wawasan Kebangsaan kepada anggotanya. Pada Keluarga Pancasila, pembudayaan nilai-nilai Pancasila dapat dilakukan dengan baik. Sebagai contoh pembudayaan sila pertama Ketuhanan Yang Maha Esa dalam keluarga, Sila pertama ini dipersepsi sebagai identitas kebangsaan yang memberikan apresiasi terhadap toleransi dan perbedaan agama. Untuk itu sila pertama ini mengidentifikasi keluarga yang terdiri atas beragam agama. Artinya, bahwa perbedaan agama tidak saja diterima, melainkan mereka juga dapat hidup rukun dalam keberagaman agama tersebut. Dalam keluarga Pancasila, tidak saja tumbuh kembang masalah pengakuan terhadap perbedaan, melainkan juga sekaligus bagaimana hidup rukun dalam keberagaman dan perbedaan tersebut.

Apabila kita telah mampu mewujudkan Keluarga Pancasila sebagaimana contoh di atas, maka sebenarnya kita telah berhasil menerapkan nilai karakter keluarga untuk mendukung pengembangan pariwisata. Dalam Keluarga Pancasila dilakukan pembudayaan sikap hidup yang tertib, saling menghormati, saling menasehati, sopan santun, tenggang rasa, dan saling menyayangi. Sikap dan perilaku hidup yang damai dalam Keluarga Pancasila ini merupakan pembelajaran yang sangat besar maknanya untuk mendukung pewujudan wilayah pesisir pantai dalam pengembangan pariwisata yang aman, nyaman, dan damai karena dihuni oleh anggota keluarga besar yang senantiasa diilhami oleh nilai-nilai Pancasila dan nilai kebangsaan dalam kehidupan sehari-hari.

\section{B. Mem-Pancasila-kan Pendidikan Nasional}

Sesuai dengan ketentuan Undang-Undang Sisdiknas, bahwa pendidikan nasional berfungsi mengembangkan kemampuan dan membentuk watak serta peradaban bangsa yang bermartabat dalam rangka mencerdaskan kehidupan bangsa, bertujuan untuk berkembangnya potensi peserta didik agar menjadi manusia yang beriman dan bertakwa kepada Tuhan Yang Maha Esa, berakhlak mulia, sehat, berilmu, cakap, kreatif, mandiri, dan menjadi warganegara yang demokratis serta bertanggung jawab. Apabila dicermati rumusan dalam Undang-Undang Sisdiknas tersebut, ternyata fungsi pendidikan nasional tiada lain adalah mengantarkan generasi muda agar berkembang kemampuannya serta terbentuk watak dan peradaban bangsa yang bermartabat. Dengan pendidikan nasional, semua peserta didik termasuk masyarakat harus dapat berkembang kemampuannya, wataknya serta peradaban bangsanya yang bermartabat. Anak bangsa yang berwatak 
dan cerdas, dalam mengarungi bahtera kehidupannya akan senantiasa bersikap arif dan bijaksana, senantiasa mengedepankan pertimbangan akal sehatnya dalam memutuskan segala sesuatu serta mampu mengendalikan emosinya. Sehingga semua tindakan yang dilakukan dalam kehidupannya senantiasa mengutamakan kepentingan masyarakat, bangsa, dan negara dibandingkan dengan kepentingan pribadinya.

Dengan demikian pada hakekatnya fungsi dan tujuan pendidikan nasional tiada lain adalah untuk mengantarkan peserta didik menjadi manusia Pancasila yang indikatornya seperti tertuang di dalam rumusan fungsi dan tujuan tersebut. Oleh karena itu semua jenis mata pelajaran di semua jenis dan jenjang pendidikan harus memmberikan kontribusi pada pencapaian fungsi dan tujuan nasional, yaitu agar peserta didik menjadi manusia Pancasila. Sebagai konsekuensinya, seluruh pendidik di semua jenis dan jenjang pendidikan apapun mata pelajaran yang diampunya, harus senantiasa memberikan kontribusi terhadap pencapaian manusia Pancasila. Bahkan kegiatan ekstra kurikuler juga harus berkontribusi dalam upaya pembidayaan nilai-nilai Pancasila dan nilai kebangsaan Indonesia.

\section{Mem-Pancasila-kan masyarakat}

Dalam mensukseskan pembudayaan nilai-nilai Pancasila dan wawasan kebangsaan di Indonesia kepada masyarakat, maka yang perlu dilakukan adalah menumbuhkembangkan sadar Pancasila kepada seluruh lapisan masyarakat. Sadar Pancasila merupakan sebuah konsep yang menggambarkan partisipasi dan dukungan masyarakat dalam mendorong terwujudnya suasana kehidupan yang kondusif bagi pelaksanaan pembudayaan tersebut.

Secara kodrati sejatinya karakteristik masyarakat dan bangsa Indonesia adalah masyarakat Pancasila, yaitu masyarakat yang toleransinya sangat tinggi, guyub rukun, kekeluargaan, gotong royong, tolong menolong, bekerjasama, dan sebagainya. Pendiri negara sudah mencontohkan bahwa kecintaan terhadap persatuan, kebersamaan, dan tanah airnya melebihi dari pada kecintaan terhadap keluarga, kelompok, dan bahkan agama sekalipun. Sebagai buktinya adalah ketika ada penolakan terhadap rumusan sila pertama dalam Piagam Jakarta saat akan ditetapkan menjadi Pembukaan UUD 1945, maka tokoh Agama Islam meskipun jumlahnya mayoritas tetap merelakan dihapusnya tujuh kata pada sila pertama, demi menjaga kebersamaan, persatuan, dan cinta tanah airnya.

Oleh karena itu untuk mem-Pancasila-kan masyarakat Indonesia sebenarnya hanya memerlukan upaya menegaskan dan membudayakan kembali nilai-nilai Pancasila dan wawasan kebangsaan sebagai jati diri dan kepribadian mereka. Banyak sekali contoh dalam kehidupan masyarakat sehari-hari yang mencerminkan pengejawantahan dari pembudayaan nilai-nilai Pancasila dan wawasan kebangsaan kepada masyarakat, seperti

\section{Paguyuban Lansia Dusun Mancingan Desa Parangtritis} Bantul.

Dalam setahun terakhir ini, masyarakat Dusun Mancingan Desa Parangtritis Bantul merintis terbentuknya Paguyuban Lansia, dengan kegiatan senam lansia, pengajian untuk lansia, penyuluhan pola hidup sehat, pemeriksaan kesehatan gratis, dan pembagian makanan yang bergizi secara gratis. Pada saat memulai kegiatan ini, banyak hambatan yang dijumpai seperti banyak warga lansia yang tidak mau bergabung karena sudah lanjut usia sehingga merasa malu bertemu dengan orang banyak dan mengalami kesulitan untuk datang ke balai dusun. Berkat kegigihan dan kerjasama antara tokoh masyarakat dengan ibu-ibu PKK, dan karang taruna, semua kendala dapat diatasi. Para pemuda bergantian menjemput dan ngantar warga lansia dari rumah ke balai dusun dan sebaliknya. Ibu-ibu PKK menyiapkan konsumsi untuk memberikan makanan bergisi bagi lansia. Tokoh masyarakat mencarikan pelatih senam dan guru yang memberikan siraman rohani serta menghubungi puksesmas dan dinas sosial. Sejumlah 200 lansia saat ini tergabung dalam paguyuban tersebut yang setiap selapan sekali mengadakan kegiatan yang selalu ditunggu-tunggu oleh warga lansia di dusun tersebut.

\section{KeSIMPULAN}

- Masyarakat Dukuh Mancingan, Parangtritis, Kretek, Bantul DIY mempunyai kesadaran untuk memperkuat nilai-nilai kearifan lokal untuk mendukung pengembangan pariwisata pada era global.

- Masyarakat Dukuh Mancingan, Parangtritis, Kretek, Bantul DIY memiliki pengetahuan dan pemahaman serta motivasi untuk menjaga kelestarian lingkungan melalui kegiatan penghijauan dan pengelolaan sampah.

- Masyarakat, terutama generasi muda Dukuh Mancingan, Prangtritis, Kretek, Bantul DIY memiliki pengetahuan yang masih terbatas tentang sejarah Parangtritis dan Parangkusumo.

- Komunikasi antara generasi muda dan orang tua yang ada di Mancingan terjalin dengan sangat baik yang diwujudkan dalam kegiatan posyandu lansia. Kegiatan tersebut digerakkan oleh para pemuda pemudi yang memberikan layanan kepada para orang tua.

- Penguatan nilai karakter masyarakat untuk mendukung pengembangan pariwisata dilakukan melalui pembentukan keluarga Pancasila, mem-Pancasila-kan pendidikan nasional, dan pembentukan masyarakat Pancasila.

\section{REFERENSI}

[1] Nandi. 2008. Pariwisata dan Pengembangan Sumder Daya Manusia. Jurnal GEA Jurusan Pendidikan Geografi, Volume 8, No. 1. April 2008.

[2] Purwaningsih, O., Tri Kusumastuti, Darsono, Triwahana. 2016. Desain Pengelolaan Wilayah Pesisir Pantai Berbasis Masyarakat. Jurnal Riset Daerah Vol. XV No 1.Badan Perencana Pembangunan Daerah Kabupaten Bantul, DIY. p: 2385 - 2395 
Jurnal Pengabdian Masyarakat J-DINAMIKA, Vol. 3, No. 2, Desember 2018,

P-ISSN: 2503-1031, E-ISSN: 2503-1112

[3] Kutanegara, Pande Made. 2014. Manusia, Lingkungan, dan Sungai : Transformasi Sosial Kehidupan Masyarakat Sempadan Sungai Code. Yogyakarta :Penerbit Ombak UGM.

[4] Syarief, E. 2010. Pembangunan Kelautan dalam Konteks Pemberdayaan Masyarakat Pesisir. www.bappenas.go.id/index.php/download file/view/

[5] Sunaryo, Bambang. 2013. Kebijakan Pembangunan Destinasi Pariwisata. Konsep dan Aplikasinya di Indonesia. Yogyakarta : GAVA MEDIA.

[6] Trisbiantoro, D., S. Oetami Madyowati, dan N. Trisyani. 2013. Model Pemberdayaan Masyarakat Kawasan Pesisir Kecamatan Watulimo, Kabupaten Trenggalek. Jurnal Mitra Ekonomi dan Manajemen Bisnis, Vol. 4 No. 1. p: 18-29.

[7] Thomas Lickona. 2013. Educating For Character : Mendidik untuk Membentuk Karakter. Jakarta : PT. Bumi Aksana. 